\title{
Breast feeding and the risk of childhood acute lymphoblastic leukemia in Mosul-a case control study
}

\author{
Mazin M. Fawzi,* Zaid M. Yassen,** \\ *Dept. of Pediatrics, **Community Medicine, College of Medicine, University of Mosul.
}

(Ann. Coll. Med. Mosul 2008; 34(2): 161-166).

Received:13 ${ }^{\text {th }}$ July 2008; Accepted: $24^{\text {th }}$ Sept 2008.

\begin{abstract}
Context: leukemia is the most common malignancy in childhood; many studies were conducted to explore the probable protective effect of breast feeding on childhood leukemia.

The aim of the present study is to evaluate the effect of breast on the development of childhood leukemia.

Methods: A case control design was conducted at the hematology unit;lbn Alatheer pediatrics hospital in Mosul city. A total of 71 children diagnosed to have acute lymphoblastic leukemia and 70 children diagnosed to have diseases other than malignancy were included in the study as cases and controls respectively. SPSS and excel computer programs, chi squared test and Z test of two proportions, were used in statistical analysis.
\end{abstract}

Results: The present study observed a protective association between breast feeding and the risk of childhood leukemia $(\mathrm{OR}=0.2, \mathrm{P}<0.05)$. Moreover, the study showed increased risk of leukemia among children exposed to explosions near their residency ( $O R=3.9, P<0.001)$.

Conclusions: Breast feeding might have a vital protective effect against childhood leukemia. On the other hand, exposure to explosive materials might carry a high risk for developing leukemia.

$$
\begin{aligned}
& \text { الخلاصة } \\
& \text { الهـفف: تهدف الدراسـة إلى تقيميم العلاقـة بين الرضـاعة الطبيعيـة وخطورة الإصـابة بابيضـاض الدم عند الأطفال في }
\end{aligned}
$$

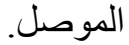

$$
\begin{aligned}
& \text { طريقة الدراسة: در اسة العينة و الثشاهد. } \\
& \text { مكان الاراسة: وحدة أمر اض الدم / مستشفى ابن الأثثر للأطفال في الموصل } \\
& \text { قيـاس المحصلة النهائيسة: تم تحليل النتـائج باستخدام برنـامجي SPSS و excel للحاسب الإلكترونـي وقد تم اسـتخدام } \\
& \text { اختباري X و } \text { و في التحليل الإحصائي. }
\end{aligned}
$$

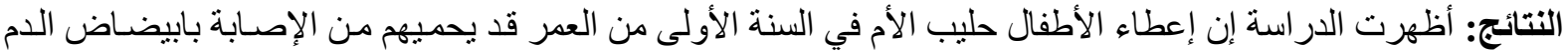

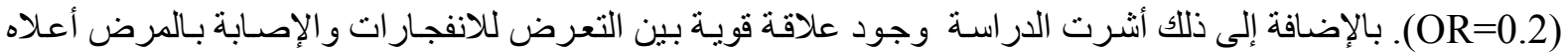

$$
\begin{aligned}
& \text {. (OR=3.9) } \\
& \text { الاستتتاج: في ضوء أنتائج الدر اسة يمكن الاستتناج بأن حليب الأم يحمي الطفل من الإصابة بابيضاض الدم. }
\end{aligned}
$$

I eukemia is the most common $\checkmark$ malignancy in childhood with a worldwide average annual incidence of 3.8-4.8/100000 children aged $0-14$ years $^{(1)}$. Globally leukemia accounts for $30 \%$ of all childhood malignancies with $75 \%$ being diagnosed as acute lymphoblastic leukemia (ALL) $)^{(1-3)}$. The incidence of $A L L$ is higher among males than females and among whites than among blacks $^{(1-4)}$. Although the etiology of childhood leukemia has been studied for more than 50 years, causal factors are largely unidentified. 
Certain conditions such as Down's syndrome, genetic abnormalities, Fanconi's anemia, and exposure to ionizing radiation thought to explain a small percentage of cases of leukemia ${ }^{(1,2,5)}$.

The infectious etiology of leukemia continues, to be explored with a potential for bacterial and viral sources. After viruses were identified as the cause of some leukemias in animals, an etiological hypothesis for human leukemia has been introduced ${ }^{(6,7)}$. On the other hand, there are some epidemiological observations of geographic clusters of leukemia cases suggesting common exposures (eg: infections) may play a role ${ }^{(8)}$.

Current etiologic researches suggest that in utero exposure (eg: prenatal drugs and dietary exposure) are implicated in the causation of infant leukemia while infection and environmental factors after birth might play a role in the proliferation of leukemia clone ${ }^{(9-11)}$.

Speculations have been focused recently on the role of breast feeding in protecting children from diseases including malignancies ${ }^{(12,}{ }^{13)}$. Human milk has long been recognized as providing numerous antimicrobial, antiinflammatory, and immunomodulating agents. Many studies have shown that breast feeding protects against infections through transmission of maternal antibodies, macrophages, and lymphocytes ${ }^{(12,14,15)}$. Human milk contains numerous immune-related compounds, and there is a comprehensive literature on the potential immune effects of human milk $^{(16)}$. Several immune-related compounds are present in breast milk. Several of these components of milk offer passive protection in the upper respiratory system and the gastrointestinal tract, preventing adherence of pathogens to the mucosa, and thereby protect the infant against invasive infections. There are data suggesting that breast milk stimulates the child's own immune system as well ${ }^{(17)}$.

Several lines of evidence support the hypothesis that the child's own immune system is influenced by breast milk. The thymus plays an important role in the maturation of the immune system. Ultrasound measures of thymus size in healthy Danish infants at 4 months of age revealed that the thymus of breast-fed infants is twice the size of that in formula-fed infants ${ }^{(18)}$.

In conclusion, the most important short-term benefit of breast-feeding is the protection against infectious diseases, which can be explained by the immune factors in human milk, of which the most important are $\lg A$ antibodies. There is also evidence that breastfeeding influences the development of the infant's own immune system, which could be the reason that some immune-related diseases such as inflammatory bowel diseases, childhood cancers, and type I diabetes seem to be less prevalent in breast-fed infants. The effect on atopic diseases is not so clear. There seems to be a protective effect against asthma, but the effect on atopic dermatitis is more doubtful, especially in infants without a family history of atopic disease ${ }^{(17)}$.

Based on these facts, investigators hypothesized that breast feeding could reduce the risk of childhood leukemia, and many studies all over the world suggest that breast feeding protects children from developing childhood leukemia $^{(7,12,19-21)}$.

The aim of the present study is to evaluate the probable protective effect of breast feeding on the development of childhood leukemia in Mosul.

\section{Patients and Methods:}

The study was conducted over 1 year period from the 1st of April 2007 to the 1st of April 2008. In order to achieve the aim of the present study, case control design has been adopted. The study sample includes 71 children aged $\leq 15$ years, and diagnosed to have ALL who consult hematology unit in Ibn Alatheer pediatrics hospital in Mosul. On the other hand, 70 children with the same age group who were consulting the same hospital and diagnosed to have any other disease than malignancy were chosen as controls. Unpaired sampling technique was used in the study; matching for age was conducted.

Every child included in the study sample was interviewed and examined by the investigators in the presence of the parents. A questionnaire form was completed for every child which includes age, sex ,residency, in 
addition to information regarding the probable factors than can be associated with ALL including type and duration of feeding in infancy, positive family history for leukemia, exposure to parental smoking, and history of exposure to explosion in a distance $\leq 1 \mathrm{~km}$ from their residency.

Data analysis was done by using SPSS and excel computer systems; odds ratio has been calculated for every factor dealt with in this study with its $95 \%$ confidence interval. Chi squared test and $Z$ test for two proportions were used for the measurement of the statistical significance.

\section{Results:}

The present study showed that ALL was more frequent in males than in females $(60.6 \%$ and $39.4 \%$ respectively) and the difference was statistically significant $(P=0.03)$. Moreover, about $47 \%$ of the cases were observed in the age group 5-10 years, Table (1).

Table (2) shows the distribution of the study population according to the type of feeding during infancy. It is evident that the frequency of breast feeding for a duration $\geq 6$ months (compared to those with no history of breast feeding) was higher among controls than among cases $(81.4 \%$ and $73.3 \%$ respectively) with odds ratio 0.2 and the difference between the two groups was statistically significant $(\mathrm{P}<0.05)$. In addition, the 95\% confidence interval for the odds ratio was found to be 0.05-0.87.

On the other hand, Table (3) shows the distribution of the study population according to some probable risk factors for ALL. It is evident that positive family history for leukemia, and parental smoking had nearly a similar frequency among cases and controls with odds ratio 1.06 and 1.46 respectively.

Moreover, unfortified milk feeding during infancy was found to be more frequent among cases than among controls $(14 \%$ and $8.6 \%$ respectively) with odds ratio 1.75 ; the difference was not significant $(P>0.05)$. Place of residency was found to be similarly distributed among cases and controls $(35.2 \%$ and $35.7 \%$ respectively) with odds ratio 1.03 .

Nevertheless, the frequency of exposure to explosions was much higher among cases than among controls $(39.4 \%$ and $14.3 \%$ respectively) with a very highly significant statistical difference $(P<0.001)$, odds ratio was found to be 3.9 with $95 \%$ confidence interval 1.78-8.85.

Table (1) Age and sex distribution of all cases .

\begin{tabular}{|c|c|c|c|c|c|c||}
\hline \multirow{2}{*}{ Age } & \multicolumn{2}{|c|}{ Male } & \multicolumn{2}{c|}{ Female } & \multicolumn{2}{c|}{ Total } \\
\cline { 2 - 7 } & No & $\%$ & No & $\%$ & No & $\%$ \\
\hline \hline $0-<5$ & 13 & 18.3 & 8 & 11.3 & 21 & 29.6 \\
\hline $5-<10$ & 18 & 25.4 & 15 & 21.1 & 33 & 46.5 \\
\hline $10-\leq 15$ & 12 & 16.9 & 5 & 7.0 & 17 & 23.9 \\
\hline Total & 43 & 60.6 & 28 & 39.4 & 71 & 100 \\
\hline
\end{tabular}

Table (2) Distribution of the study population according to type and duration of feeding during infancy.

\begin{tabular}{|c|c|c|c|c|c|c|c|}
\hline \multirow[t]{2}{*}{ Breast Feeding } & \multicolumn{2}{|c|}{$\begin{array}{c}\text { Cases } \\
(n=71)\end{array}$} & \multicolumn{2}{|c|}{$\begin{array}{c}\text { Controls } \\
(n=70)\end{array}$} & \multirow[t]{2}{*}{ OR } & \multirow[t]{2}{*}{$\mathbf{P}$} & \multirow[t]{2}{*}{$95 \%$ CI } \\
\hline & No & $\%$ & No & $\%$ & & & \\
\hline Duration $\geq 6$ months & 52 & 73.3 & 57 & 81.4 & $0.2 *$ & $<0.05^{*}$ & 0.05-0.87 \\
\hline Duration $<6$ months & 10 & 14.1 & 11 & 15.7 & $0.2 * *$ & $>0.05 * *$ & 0.04-1.05 \\
\hline $\begin{array}{c}\text { No history of breast } \\
\text { feeding }\end{array}$ & 9 & 12.6 & 2 & 2.9 & - & - & - \\
\hline
\end{tabular}

*Breast feeding for Duration $\geq 6$ months Vs No history of breast feeding.

** Breast feeding for Duration $<6$ months Vs No history of breast feeding. 
Table (3) Distribution of study population according to probable risk factors of leukemia .

\begin{tabular}{|c|c|c|c|c|c|c|c|}
\hline \multirow[t]{2}{*}{ Factors } & \multicolumn{2}{|c|}{ Cases $(n=71)$} & \multicolumn{2}{|c|}{$\begin{array}{c}\text { Controls } \\
(n=70)\end{array}$} & \multirow[t]{2}{*}{ OR } & \multirow[t]{2}{*}{$\mathbf{P}^{*}$} & \multirow[t]{2}{*}{$95 \% \mathrm{CI}$} \\
\hline & No & $\%$ & No & $\%$ & & & \\
\hline $\begin{array}{c}\text { Positive family history for } \\
\text { leukemia }\end{array}$ & 18 & 25.4 & 17 & 24.3 & 1.06 & $>0.05$ & $0.5-2.26$ \\
\hline Parental smoking & 35 & 49.3 & 28 & 40 & 1.46 & $>0.05$ & $0.51-2.83$ \\
\hline $\begin{array}{l}\text { Infant feeding with unfortified } \\
\text { milk }\end{array}$ & 10 & 14 & 6 & 8.6 & 1.75 & $>0.05$ & $0.62-4.92$ \\
\hline Urban residency & 28 & 35.2 & 29 & 35.7 & 1.03 & $>0.05$ & $\begin{array}{l}0.9-1.18 \\
\end{array}$ \\
\hline $\begin{array}{l}\text { Exposure to explosions in a } \\
\text { distance } \leq 1 \mathrm{~km}\end{array}$ & 28 & 39.4 & 10 & 14.3 & 3.9 & $<0.001$ & $1.78-8.85$ \\
\hline
\end{tabular}

* Chi squared test is used.

\section{Discussion:}

Leukemia is the leading cause of morbidity among children less than 15 years of age ${ }^{(22)}$. Currently, the causes of childhood leukemia are not well known although sex, age, race, ionizing radiation, and specific genetic syndromes, have been consistently shown to be associated with increased risk of leukemia ${ }^{(22)}$.

The present study observed that ALL was more common among males than among females, with male to female ratio 1.54:1. Similar results have been found in other studies conducted by Zack et al, Kaye et al, and Cartwright et al ${ }^{(23-25)}$.

The scientific evidence has been mixed regarding the association of breast feeding and childhood leukemia. A number of studies showed no association between breast feeding and leukemia risk, however, many recent studies suggest that breast feeding protects children from developing leukemia ${ }^{(12)}$.

The present study observed a negative association between breast feeding for a duration $\geq 6$ month, and the risk of childhood leukemia $(O R=0.2)$. This result supports the theory that breast feeding protects children against leukemia.

Similar results have been observed in many other studies conducted all over the world. Van Duisu et al in Netherlands and Davis et al in USA observed a negative association between breast feeding and leukemia $(\mathrm{OR}=0.83 \text { and } 0.68 \text { respectively })^{(26,27)}$. Moreover, similar negative association was observed in other studies conducted in
Germany and Canada 1999 (OR= 0.77 and 0.72 respectively $)^{(19,28)}$.

Nevertheless, the present study also found a negative association between shorter duration of breast feeding ( $<6$ months) and the risk of childhood leukemia $(O R=0.2)$ but the difference was not significant $(p>0.05)$ which might be due to the relatively small sample size. Although other studies conducted in UK 2001 observed a significant negative association between breast feeding for duration $<6$ months, and the risk of leukemia $(\mathrm{OR}=0.25)^{(29)}$, Hardell et al in Sweden 2001 found no association between breast feeding $<6$ months and leukemia $(\mathrm{OR}=1)^{(30)}$.

A meta analysis was conducted in 2004 and reviewed 30 articles, which evaluated the association between breast feeding and childhood leukemia. The meta analysis observed a protective association between both short and long term breast feeding and childhood leukemia ${ }^{(12)}$.

On the other hand, the present study failed to find an association between the presence of some factors such as parental smoking, positive family history, feeding unfortified milk during infancy, and residency and the development of leukemia, although another study conducted in UK observed an association between parental smoking and leukemia $^{(31)}$.

Nevertheless, the present study observed a very highly significant positive association between leukemia and exposure to explosions in a distance $\leq 1 \mathrm{~km}$. $(\mathrm{OR}=3.9, \mathrm{P}<0.001)$. This association might be attributed to the exposure 
to some carcinogenic chemicals or radioactive substance, which are products of the explosive materials, in addition to the severe psychological trauma on those children. There are many well documented cases of radiation induced cancer in human, some epidemiological studies postulated that even the exposure to small doses of radiation increase the risk of cancer significantly ${ }^{(32)}$.

In bomb survivors and other irradiated populations the increase in risk of leukemia has appeared within 2-5 years after exposure ${ }^{(33)}$. A cohort study conducted in Japan showed that the relative risk of leukemia at atomic bomb survivors at 1950-1985 was five $e^{(34)}$.

\section{Conclusions and Recommendations:}

From the results of the present study, the following conclusions can be stated:

1. Breast feeding has a vital role in preventing childhood leukemia.

2. The exposure to explosions in near distance might carry a high risk for the development of childhood leukemia.

3. No association could be observed between place of residence and positive family history and the development of childhood leukemia. It is worthwhile to conduct other studies in Iraq to evaluate and observe the risk factors of childhood leukemia especially the exposure to explosive materials and to evaluate the protective effect of breast feeding.

\section{References:}

1. National Cancer Institute. National Cancer Institute research on childhood cancers. Available at: http://cis.nci.nih.gov/fact/6 40.htm.

2. Richard E., Robert, M. Nelson essentials of pediatrics, Elsevier, Philadelphia, $5^{\text {th }}$ edition, 2005: 590-596.

3. Indith C., Murray L., Peter S. Oxford handbook of clinical specialties, Oxford University Press, New York, $6^{\text {th }}$ edition, 2003: 190-191.

4. American Cancer Society. What are the key statistics about childhood leukemia? Available at:www.cancer.org/docroot/CRI/content/CRI_
2_4_1X_What_are_the_key_statistics_about childrnav $=$ cri.

5. Boice J, Land C, Preston D. Ion radiation. In: Schottenfeld D, Fraumeni J, eds. Cancer Epidemiology and Prevention. $2^{\text {nd }}$ ed. New York, NY: Oxford University Press; 1996.

6. Evans AS, Mueller NE. Viruses and cancer. Causal association. Ann Epidemiol. 1990; 1: 71-92 [Medline].

7. Jeanne G., Donald A., Cynthia M. Review of case control studies related to breast feeding and reduced risk of childhood leukemia. Pediatrics, 2005; (116)5: 724-731.

8. Department of Health and Human Services. HHS Blueprint for Action on Breastfeeding. Washington, DC: office on Women's Health, Department of Health and Human Services; 2000. Available at: www.4woman.gov/Breastfeeding/bluprntbk2. pdf.

9. Greaves M. Childhood leukemia. BMJ 2002; 324:283-7.

10.RossJA, Dietry flavonoids and the MLL gene: a pathway to infant leukemia? Proc Natl Acad Sci 2000; 97: 4411-3.

11.Alexander FE, Patheal SL, Biondi A, et al. Transplacental chemical exposure and risk of infant leukemia with MLL gene fusion. Cancer Res 2001; 61: 2542-6.

12.Marilyn L., Patricia A., Barbra A. Breast feeding and the risk of childhood leukemia: A meta analysis. Public health reports. 2004; 119: 521-535.

13. Greaves M. Molecular genetics, natural history and the demise of childhood leukemia. Eur I Cancer 1999; 35: 1941-53.

14. Goldman AS. The immune system of human milk: antimicrobial, anti-inflammatory and immunomodulating properties. Pediatr Infect. Dis J 1993; 12: 664-71.

15.Kramer MS, Chalmers B, Hodnett ED. Sevkovskaya Z, Dzikovich I. Shapiro S, et al. Promotion of Breastfeeding Intervention Trial (PROBIT): a randomized trial in the Republic of Belarus. JAMA 2001; 285: 413-20.

16. Hanson L. Immunobiology of human milk: how breastfeeding protects infants. Amarillo, TX: Hale Publishing; 2004.

17.Lene Schack-Nielsen, Kim F. Advances in Our Understanding of the Biology of Human 
Milk and Its Effects on the Offspring. J. Nutr. 2007; 137:503S-510S.

18. Hasselbalch $H$, Jeppesen $D L$, Engelmann MD, Michaelsen KF, Nielsen MB. Decreased thymus size in formula-fed infants compared with breastfed infants. Acta Paediatr. 1996;85:1029-32. [Medline]

19.Shu XO, Linet MS, Steinbuch M, Wen WQ Buckley JD, Neglia JP, et al. Breastfeeding and risk of childhood acute leukemia. J Natl Cancer Inst 1999; 91: 1765-72.

20.Smulevich VB, Solionova LG, Belyakova SV. Parental occupation and other factors and cancer risk in children: I. Study methodology and non-occupational factors. Int $\mathrm{J}$ Cancer 1999; 83: 712-7.

21. Infante-Rivard C, Fortier I, Olson, E. Markers of infection, breastfeeding and childhood acute lymphoblastic leukemia. $\mathrm{Br} \mathrm{J}$ Cancer 2000; 83: 1559-64.

22.Smith M, Ries L, Gurney J, Ross J. Leukemia. In: Ries L, Smith M, Gurney J, Linet M, et al., editors. Cancer incidence and survival among children and adolescence: United States SEER program 1975-1995. Bethesda (MD): National Cancer Institute, SEER Program; 1999. p. 17-34.

23.Zack M, Adami HO, Ericson A. Maternal and Perinatal risk for childhood leukemia. Cancer Res 1991; 51: 3696-701.

24. Kaye SA, Robison LL, Smithson WA, Gunderson P, King FL, Neglia JP. Maternal reproductive history and birth characteristics in childhood acute lymphoblastic leukemia. Cancer 1991; 68: 1351-5.

25.Cartwright RA, Gurney KA, Moorman AV. Sex ratios and the risks of haematological malignancies. Br Haematol 2002; 118: 10717.

26.van Duijn CM. van Steensel-Moll HA, van der Does-vd Berg A, van Wering ER, van
Zanen GE, Valkenburg HA, Rammeloo JA. Infant feeding and childhood cancer [letter]. Lancet 1988; 2: 796-7.

27.Davis MK, Savitz DA, Graubard, BI. Infant feeding and childhood cancer. Lancet 1988; 2: 365-8.

28.Schüz J, Kaletsch U, Meinert R, Kaatsch $P$, Michaelis J. Association of childhood leukemia with factors related to the immune system. Br J Cancer 1999; 80: 585-90.

29.UK Childhood Cancer Study Investigators. Breastfeeding and childhood cancer. $\mathrm{Br} \mathrm{J}$ Cancer 2001; 85: 1685-94.

30. Hardell L, Dreifaldt AC. Breastfeeding duration and risk of malignant diseases in childhood in Sweden. European J Clin Nutr 2001; 55: 179-85.

31.Xiao S., Martha L., Michael S. Breastfeeding and risk of childhood acute leukemia. Journal of the national cancer institute, 1999; (91) 20: 1765-1772.

32.Cancer risk coefficient for environmental exposure to radionuclide, Federal guidance report No 13, EPA 402-R-99-001, US environmental protection Agency, Washington DC, 1999.

33.Robert B, Bardey N. Public health and preventive medicine ,Appleton and Lange Stamford, Connecticant, $14^{\text {th }}$ edition, 1998:619-626.

34. Shimizu Y, Kato h, Schull WJ. Studies of the mortality of bomb survivors. Mortality 19501985: part 2 cancer mortality based on recently revised doses (DS 86). Radiat Res,1990; 121:120-141. 